\title{
The Social and the Impact of COVID-19 on Social Behavior in Streets of Amman, Jordan
}

\author{
Majd AlBaik ${ }^{1 *}$, Wael Al-Azhari ${ }^{2}$ \\ ${ }^{1}$ The Department of Architecture, Faculty of Engineering, the Hashemite University, Zarqa 13133, Jordan \\ ${ }^{2}$ Department of Architecture Engineering, School of Engineering, the University of Jordan, Amman 11942, Jordan
}

Corresponding Author Email: majdm@hu.edu.jo

https://doi.org/10.18280/ijsdp.160511

Received: 23 July 2021

Accepted: 3 September 2021

\section{Keywords:}

COVID-19, dynamic spaces, public spaces, streets design, human behavior, physical quality

\begin{abstract}
Governments around the world enforced many restrictions according to the recommendations of the World Health Organization (WHO) and tried very hard to minimize spread of epidemic in their countries. One of these restrictions is on using of public spaces that led to create new challenges to think about how we design public spaces and the way of using the most dynamic nearby spaces around us such as streets. The main objectives of this research are to measure the impact of COVID-19 on behavior of local community in public street. And to what extend changed of social behavior in public streets to compensation the absence of public spaces, where they became a breathing space for locals in Amman, Jordan. Also to addresses these questions which are focused on how the local community deals physically with the COVID19 situation? And what are the changes that are done in their behavior to entertain themselves during the COVID-19 pandemic? Researchers carried out an analysis by using a mixed used approach; qualitative and quantitative methods through executing a questionnaire and a field observation of the study area which is selected. In conclusion, the results of the study showed that activities of local residents have changed between in the lockdown of COVID-19 pandemic and beyond whereas there has been more demand on active lifestyles which is continue after COVID-19 pandemic as new behavior of local residents. although the physical quality of the street are not design to meet new behavior.
\end{abstract}

\section{INTRODUCTION}

Nowadays the whole world countries facing a universal pandemic, governments have been struggling to contain the consequences of the pandemic and to minimize the diffusion coefficient. Each one of these governments enforce many restrictions according to the recommendations of the World Health Organization (WHO) and trying hardly to minimize consequences of the epidemic in their countries. On the other hand, the citizens should be commitment to new laws for example wearing mask and keeping a safety distance from each other. Moreover, commit citizens to work from home while at the same time home-schooling their children, as a consequence people feels that have been isolated from their loved ones. So they tried to find new ways of living and working virtually but that encouraged the feeling of further pressures. in addition, restrict on using public spaces which leaded to create new challenges to think about how we can deal with this situation and try using the most dynamic nearby spaces around us such as streets, to find a place to ease pressure.

Many researchers have been writing about how the public spaces are affected by expecting future design with a social distance and the relationship how has been changed between users [1,2] also the cultural aspect of new social distance [3]. but there is a lack of research on how communities deal with streets after lockdown of COVID-19 pandemic in conjunction with the restrictions of public spaces. In the last stage of the crisis, new social behaviors have appeared that are observed in many public streets, in Amman, Jordan, to adapt with the new situation. That led to ponder how should our streets be designed especially the main streets that close to neighborhoods, because they became the only breathing space.

The main objectives of this research are to measure the impact of COVID-19 on behavior of local community in public street. And to what extend changed of social behavior in public streets to compensation the absence of public spaces, where they became a breathing space for locals in Amman, Jordan. Also to addresses these questions which are focused on how the local community deals physically with the COVID-19 situation? And what are the changes that are done in their behavior to entertain themselves during the COVID19 pandemic?

Researchers carried out an analysis by using a mixed used approach; qualitative and quantitative methods through executing a questionnaire and a field observation of the study area which is selected. This can be explained by the main part for shaping streets as a public space is understanding the relationships between users and physical environment that represent what users are able to do in these available options $[4,5]$. Therefore, the research was based the observation to evaluate the street design quality and observe the social behavior of the community. after that make a questionnaire to assess their relationship with the street. 


\section{COVID-19 PANDEMIC IN JORDAN}

Jordan is not only one of the highest countries that confirmed COVID-19 cases of the world but also a small geographical region divided into 12 governorates and each one has its unique characteristics. Amman is home to one of the most country's population. In the beginning of 2020, they reached about 10,556,008 million people [6].

The first COVID-19 confirmed case was recorded on 2nd March 2020 [7, 8]. In this paper, all information used is based on the epidemiological reports provided by the Ministry of Health in Jordan which was used to monitor the development of COVID-19 and how the government dealt with it. Jordan government had to rapidly take actions to limit the spread of the scope of the crisis and control the imminent threat.

As on 14th March 2020, the government announced suspension of schooling in schools and universities and it has had a trend towards online learning. Accompanied by many other instructions which include; Suspending all international travels considering all border crossings closed, ceased all public gatherings as confined to family members who live together, stop praying in mosques and churches and eventually emphasizing on citizens to stay at homes with required social distancing.

The second phase was critically important as it started when the number of cases increased to 84 in a short time within 18 days, according to the Ministry of Health, that was on 20th March 2020, which led to start working on Defense Laws issued by the Minister of Defense in which enacts all orders based on the current situation. Consequently, enforced strict curfew nationwide lockdown on 21th March until further notice [9].

The curfew lasted only for two days due to the lack of control on food distribution which the government decided to deliver to neighborhoods. So, the government allowed local stores to open from 10:00 AM to 6:00 PM as well as it allowed locals to move freely on foot during this time to buy groceries. As the epidemiological situation emerged and accompanied a deteriorating economic situation the government started doing an even-odd system for allowing vehicle movement and that was on 27th April 2020 between 8:00 AM and 6:00 PM, that was accompanied by allowing to resume work in some sectors gradually.

On 7th June 2020 the government announced a return to normal life gradually, after dissemination of awareness of the importance of personal protection measures. While public spaces (parks, malls, cinemas, and sports events), schools and universities continued to remain closed. As well as, work on controlling individual behavior which exceeds public health procedures that were closely monitored by the officials. In fact, until 27th January 2021, procedures are still being updated according to epidemiological situations around the world.

All of the restrictions led to create new social behaviors to look for recreation activities, and so most people have oriented to walk around their neighborhood where they found the streets are the essential part to take a breath, in the absence of the outdoor spaces in most apartments. Social behavior studies are an essential part of public life study and should be taken into consideration not only because it reflects the picture of the people's responses, but primarily because it is the driving force of our urban design.

\section{SECTION HUMAN BEHAVIOR AND STREETS}

The main question of the study is; did COVID-19 add new behaviors in streets? And how?

Evaluating the functioning of public sites is often done by counting people in streets, parks or squares and that is an indication of the effectiveness and the efficiency of these places [10]. Therefore, the meaning of spaces does not necessarily the concept of architectural design only for them but it depends on individuals' perspectives and what the activities are permitted there, so each space gets significance from their users [11-13] where are built relationship between the individuals and the identity of the place stimulated by the memory, experience and time that users spent in there. In addition, there are many restrictions defining the behaviors in each place based on qualitative changes $[14,15]$ that led to a variety of place's activity and quality of users.

Public spaces is divided into two types and therefore the behavior of user differ according to the type, formal public spaces which designed for sports and recreation so it include public sports fields, playground, fitness machines, bicycle and pedestrian lane, sitting area, so the physical activity consist in social interaction between users, ride a bike, walking, play on fitness machine, turn taking, addressing and social relationships in small groups all that are done either individually or by group $[16,17]$. This kind of public space in Jordan offers green spaces with shopping booths, a variety of seating areas (shelterd and open) and playgrounds for kids where all families can interact together, it focuses on daytime activities with security guards $[18,19]$. While, informal public spaces which aren't design as public spaces such as squares and streets where users can use all architecture element to make them interesting such as; stairs, walls, ramps, benches, street lamps, or pillars, all these used for practicing inline skating, kick scooter riding, climbing, parkour, streetball, hiphop and break dance so the users give to the place meaning and significance where can also introduce new performance for instance, dance, street art and playing music [17].

In Jordan, informal public spaces confined to sub streets within neighborhood where local neighbors can use especially children and women, where children attract others to ball game or playing on toys vehicles and the women sit and socialize with other neighbor near the main entrance of their homes [20]. however, in the main streets which collect number of neighborhood these activities were absent, but after lockdown of COVID-19 pandemic they have been appear beside other new activities related to local users.

Throughout history, streets have played a significant part in urban design as the widest and most accessible public space. Furthermore, understanding the society and the city are done by studying streets located in $[5,21,22]$.

one the other hand, invent the automobile led to replacement pathways to streets for vehicles, as a result street as an integral part of public space is neglected that has led to the emergence new terms such as livable streets which indicate to street movement which identify the healthy community by testing street design, amenities and performance which provide safety and comfort for children, women, elderly people and for who cycling and walking [23-25].

Recent evidence suggests that the constraints of COVID-19 to prevent the spread of the epidemic encourage city planners to increase the pedestrian and cyclists zone of the street space that led to a greener environment with less carbon emission $[26,27]$. Many planners discussed the need of expanding the 
sidewalk and redesign it to solve the issue of physical distancing that was recommended [1]. Milan was the first city in implementing these actions and took up a recommendation from city planners, it is demonstrated in its wider sidewalk [28]. Moreover, numerous countries such as Boston, London, Vancouver, Brussels, New York, Paris, and Barcelona have started to take action in redesign streets to welcome a lot of people [29-31].

This research focuses on analyzing human behaviors in respect to the activities taking place in streets. This can be explained by the main part for shaping streets as a public space is understanding the relationships between users and physical environment that represent what users are able to do in these available options $[4,5]$.

Factors found to be influencing quality of streets have been explored in several studies, however according to Babatunde [5], which this paper basis on it, the author classifies the relationship between quality of streets and the level of social activities that promote social interaction into three types of indicators, activity, connectivity, and perception.

The activity refers to the number of people that flow in streets and the type of users. While the connectivity indicates physical characteristics of the street such as, width of street, width of sidewalk, and the condition of both. Finally, the perception points to safety and security, sense of belonging, social interaction and comfort [5].

Reflecting the situation in Jordan which was according to the observations, that is most streets were designed to the vehicles while ignoring the pedestrian's needs to pavements for a walk. However, people need sidewalks on a wider basis these days than ever before in response to the current crisis to do more action to meet physical distance. Indeed, the streets are good opportunities for social interaction between locals such as storefront shopping, meeting with friends and for pedestrian activities. Therefore, the physical distance should be considered in designing streets.

\section{METHODOLOGY}

This research seeks to assess the essential objective that is evaluating the quality of street's design in Amman. Furthermore, measuring their work in COVID-19 pandemic or if the streets have needed to liberate more space to serve pedestrians according to physical distance in a specific street which is Queen Rania Street referred to it as Jordan University "AlJama'a" Street.

The main reason for selecting this street is to represent a good example in Amman for vital streets. Furthermore, it represents the situation of many streets that have the same condition in the physical features and attracted community after pandemic to doing physical daily life activities in open areas. The street has two sides with width 9 meters for each side, and separated by two islets with bus transit lanes width 7 meters in between. Given the fact that the study focuses on physical features of the design, the research has been studying the street along 3 kilometers with 3 types of sections to avoid extracting incorrect conclusions.

The explanation of the approach that was applied is worth mentioning. The approach of collecting data to analyze of pedestrian behavior in public street, focusing on focuses on physical activities, depends on evaluation by proposed classification scheme from different resources of information which consists mainly of the following: direct observation, first observed the physical features of the street by using factors (see Table 1) to evaluate the situation of the street.

Then observe the location carefully to identify the type of user and also the points where they concentrate each group of users. After that the users flow was monitored for a month, 3 days of a week at 3 time of day (morning 7:30-12:00, afternoon 12:00-18:00, evening 18:00-21:00) to classified the type of physical activity for users also to know the specific time for each type of activities.

Table 1. The definition of physical characters which are used

\begin{tabular}{|c|c|c|}
\hline \multirow{7}{*}{$\begin{array}{l}\text { Whole Street } \\
\text { Design }\end{array}$} & Street Width & $\begin{array}{l}\text { Means the span of space that is determined within the boundary of the street. It is measured by meters } \\
\text { at an angle of } 90^{\circ} \text { to the street itself. }\end{array}$ \\
\hline & Street Length & $\begin{array}{l}\text { That refers to the horizontal distance way between two points that were determined from the authors } \\
\text { as illustrated in pictures. }\end{array}$ \\
\hline & Side Walk Width & $\begin{array}{l}\text { It is the total width of the public space where the path exists within it. The sidewalk is usually enclosed } \\
\text { by buildings on both sides. Besides, it affects the quality of included paths. It is measured in meters. }\end{array}$ \\
\hline & Land Use & That refers to the use of the land on street sides all over the distance that was determined of street. \\
\hline & Street Furniture & $\begin{array}{l}\text { Its term for equipment were installed along streets for different purposes, in this research include; } \\
\text { benches and waste receptacles. }\end{array}$ \\
\hline & $\begin{array}{l}\text { Shaded area of } \\
\text { walking zone }\end{array}$ & $\begin{array}{l}\text { That refers to any shelter device from direct sun rays, whether hard-scape such as cantilevers or recess } \\
\text { in buildings wall and softscape as trees. }\end{array}$ \\
\hline & $\begin{array}{l}\text { Landscape } \\
\text { elements }\end{array}$ & It includes the texture and color that use to create a spatial experience and add richness to the design. \\
\hline \multirow{4}{*}{$\begin{array}{c}\text { Transit } \\
\text { Lanes Design }\end{array}$} & Width & $\begin{array}{l}\text { The span that determined the transit lane for the bus. It is measured by meters at an angle of } 90^{\circ} \text { to } \\
\text { the street itself. }\end{array}$ \\
\hline & $\begin{array}{l}\text { Paved Shoulder } \\
\text { Width }\end{array}$ & $\begin{array}{l}\text { The width of the paved shoulder that is adjacent regularly along the transit lane of the bus on both } \\
\text { sides. }\end{array}$ \\
\hline & $\begin{array}{l}\text { Path Illumination } \\
\text { Level }\end{array}$ & $\begin{array}{l}\text { The suitable levels of illumination that give the walker a feeling of safety while they walk. It has been } \\
\text { accounted for by the number of lighting units. }\end{array}$ \\
\hline & Path Floor Height & The height of pavement above ground level, it measured by meters. \\
\hline
\end{tabular}

Then making a comparison between the type of activities that are done in the street before the lockdown and after to know which kind of activities have new appearance. Finally by mapping and identification of sites of activities along the street to determine their connection with functions of the street.
Questionnaire was conducted on 150 participants randomly and the number of questionnaires valid are 98 that was to evaluate how the users are related to the street before. lockdown and beyond. and other sources such as videotapes and photographs during the period between June to August, 
2020. The collecting of the fieldwork data was started by direct observation of people activity and streets physical characteristics. This was followed by questionnaires to get deeper understanding of the study as well as the local's perceptions of social activities that they can do in streets depending on the quality of street and if they have changed after lockdown of the city due to COVID-19 pandemic.

\subsection{Research setting}

Amman is the capital of Jordan; it occupies the largest ratio of the population. It was divided into 22 areas, Figure 1, which are administered by Greater Amman Municipality (GAM). The city has rapid growth, this rapid growth led to an increased development of the infrastructure of the city and improvement of the street network to appropriately accommodate needs of the population.

The criteria that have used to justify the selection of streets areas are:

- Represent a good example in Amman for vital streets. Furthermore, it represents the situation of many streets that have the same condition in the physical features and attracted community after pandemic to doing physical daily life activities in open areas.

- $\quad$ Rich information about them.

- Location: vital street in residential areas.

- The changing in the number of users increases according to the procedure of COVID-19.

- Different types of activities were done there by users.

Brief description of street: Queen Rania Street locals referred to it as Jordan University "AlJama'a" Street, it extends from Aldawriat traffic light to city sport roundabout. However, the pedestrian concentration along Aldawriat traffic lights to Jordan University Hospital, then gradually decreased. It serves as an arterial street connecting two communities. As well as, the border of the street has a variety of commercial uses such as Jordan University, mall, grocery stores, restaurant and furniture stores, Figures 2, 3, and 4.

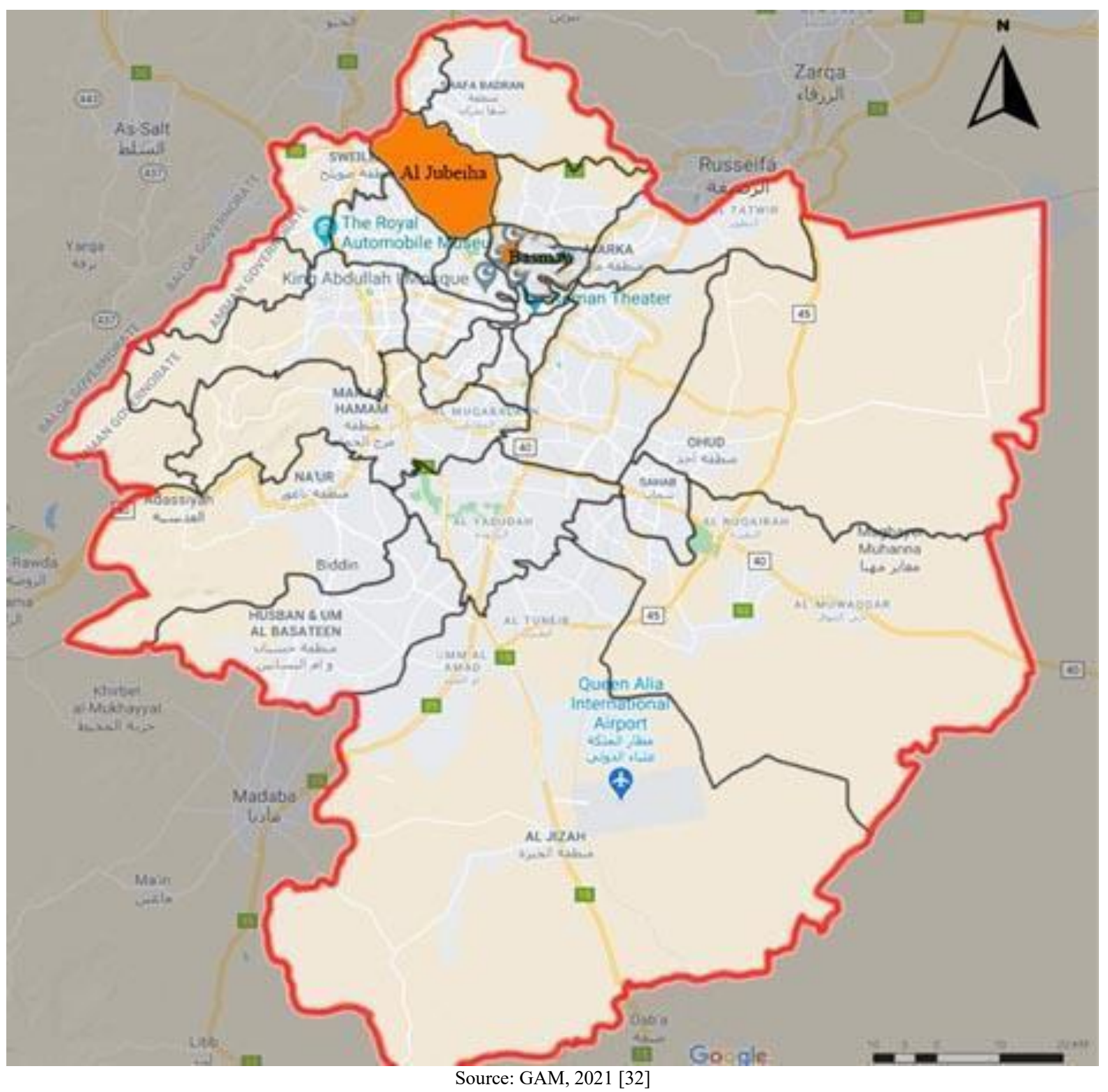

Figure 1. The location of the street within Al Jobeha neighborhood 


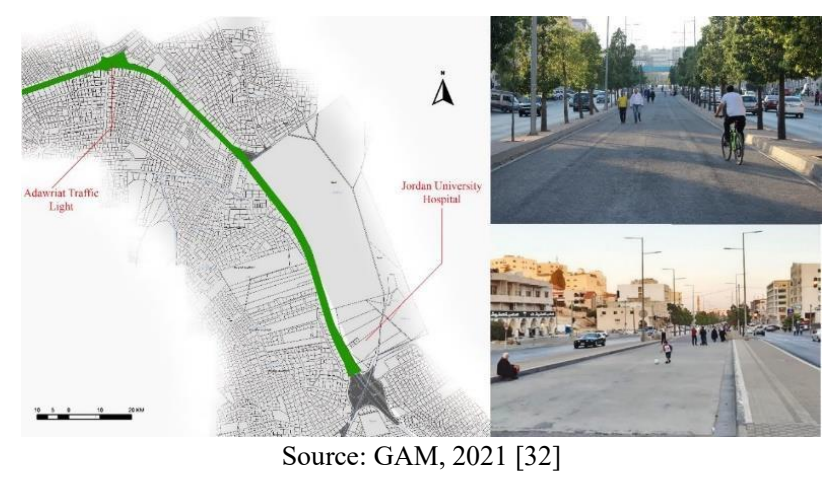

Figure 2. Map of photos of Jordan university street

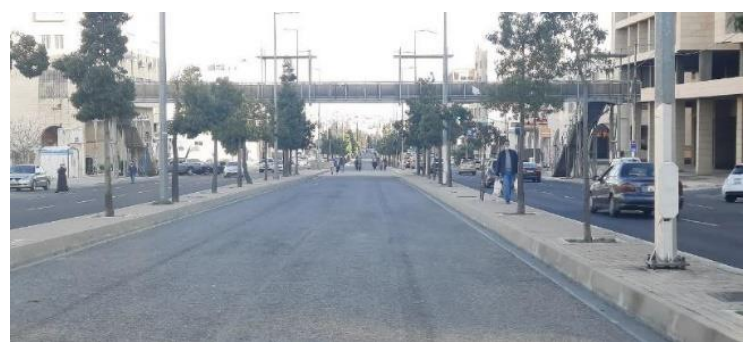

Figure 3. The Jordan university street at day-time

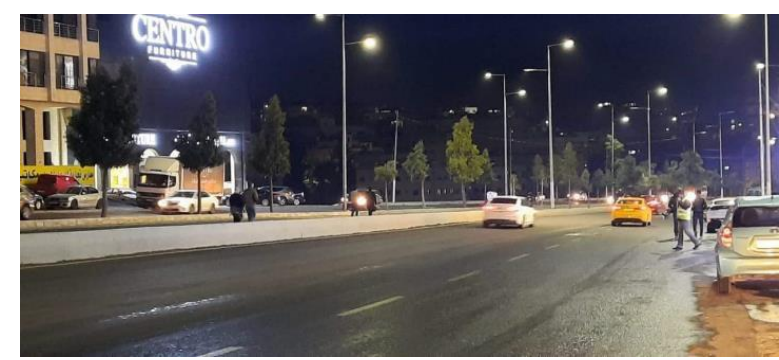

Figure 4. The Jordan university street at night

\section{DISSECTION}

\subsection{Physical feature of the street}

There are many elements that are considered as physical features and act as an essential factor in studying streets (Table 2).

The physical features of Queen Rania Street were designed mainly to serve the University of Jordan, then it became an attractive point for people to build around, stimulating it be an arterial street. but it lacks any treatment of the street for instance the main elements of the street: sidewalk, street furniture and bike lane. Recently, they have been adding twoway transit lanes for bus routes (see Figure 5). It also is regarded as a long corridor linking many areas in Amman.
This lane was designed with two paved shoulders on both sides, it allowed a buffer zone for safe space. However, it is still not working out, thereby encouraging locals to use it in a different way by creating a safe space for locals to do their activities, in the absence of any public spaces, Table 2 .
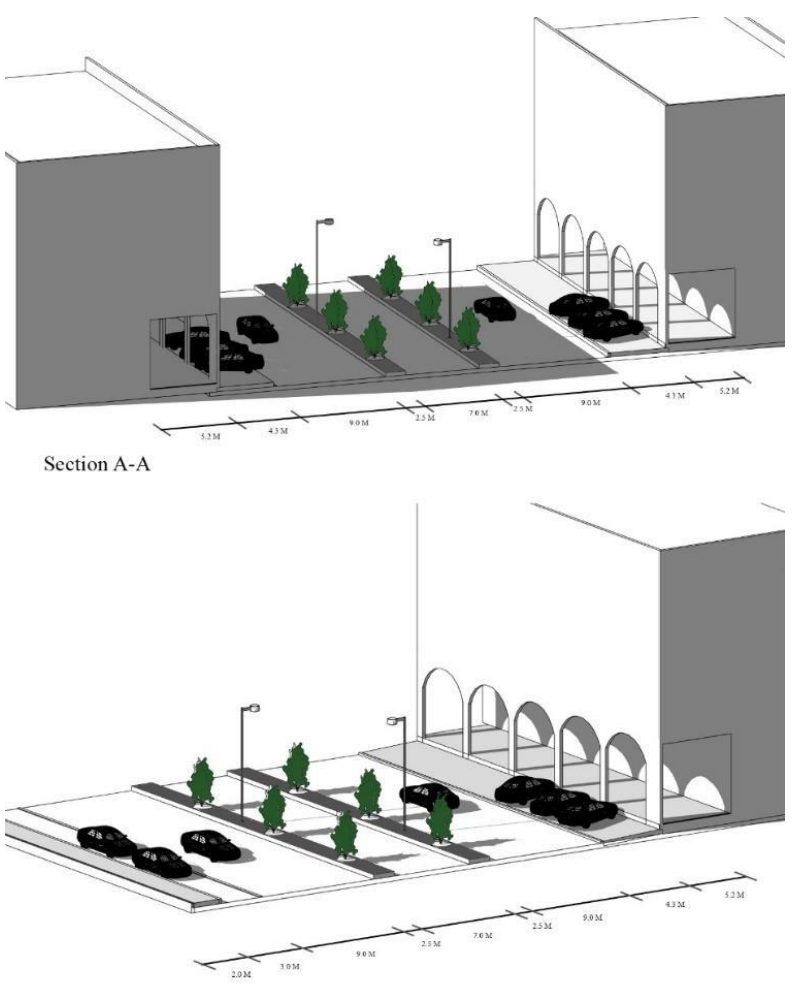

Section B-B

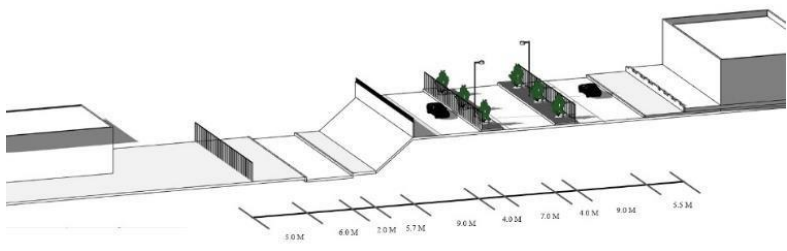

Section C-C

Figure 5. Sections in the Queen Rania street

Previous studies have explained that the narrow streets with limited vehicle speed have a stronger influence on social interaction than the wide streets with high-speed traffic, in addition, the streets which are used as a public space should be provided with effective protection to prevent accidents [33].

Table 2. Physical characters of queen Rania street

\begin{tabular}{|c|c|c|c|c|c|c|c|c|c|c|c|}
\hline \multicolumn{3}{|c|}{ Street Design } & \multirow[b]{2}{*}{ Land Use } & \multirow[b]{2}{*}{$\begin{array}{c}\text { Street } \\
\text { Furniture }\end{array}$} & \multirow[b]{2}{*}{$\begin{array}{c}\text { Shaded } \\
\text { Area of } \\
\text { Walking } \\
\text { Zone }\end{array}$} & \multirow[b]{2}{*}{$\begin{array}{l}\text { Landscape } \\
\text { Elements }\end{array}$} & \multicolumn{4}{|c|}{ Transit Lanes } & \multirow[b]{2}{*}{$\begin{array}{c}\text { Number } \\
\text { of trees }\end{array}$} \\
\hline $\begin{array}{l}\text { Street } \\
\text { Width } \\
\text { (M) }\end{array}$ & $\begin{array}{l}\text { Street } \\
\text { Length } \\
(\mathrm{KM})\end{array}$ & $\begin{array}{l}\text { Sidewalk } \\
\text { Width } \\
\text { (M) }\end{array}$ & & & & & $\begin{array}{l}\text { Width } \\
\text { (M) }\end{array}$ & $\begin{array}{c}\text { Paved } \\
\text { Shoulder } \\
\text { Width (M) }\end{array}$ & $\begin{array}{c}\text { Path } \\
\text { Illumination } \\
\text { Level }\end{array}$ & $\begin{array}{l}\text { Path } \\
\text { Floor } \\
\text { Height } \\
\text { (M) }\end{array}$ & \\
\hline 54 & 2.97 & 5.2 & Commercial & no & yes & yes & 7 & 1.5 & $\begin{array}{l}\text { High at night } \\
75 \text { light units } \\
\text { in each side }\end{array}$ & 0.3 & $\begin{array}{l}64 \text { trees } \\
\text { in each } \\
\text { side }\end{array}$ \\
\hline
\end{tabular}


Moreover, to use streets as public space and encourage social interaction should take into consideration putting an obvious path for pedestrian flow. Also there is a study that dealt with the relationship between the width of the sidewalk and how it encourages social interaction.

Additionally, the path illumination level whether from street lights or from the shops around it is important to social interaction spatially at night because it increases the feeling of safety and security during the walking [21].

\subsection{Users type}

What are users type and the activities of the streets?

The effective way to study the behavior of users involves the observation of street use with a behavioral mapping technique that includes the mapping of activity place and physical feature of streets [32]. Therefore, based on the observations (photo, sketch, activity mapping and data collection) during two weeks after lockdown of COVID-19 pandemic from 28 June to 12 July 2020, in three times of a day; morning, afternoon and evening, have been recorded the result as mapping in Figure 6.

The results recorded that the highest number of social activities are frequented during the evening and limited in daytime, since they are confined to day activities such as opening the shops, transporting goods, delivering items or going to work during the day-time.

For the purpose of comparison, the number of users for each type of activity were accounted before the lockdown of COVID-19 pandemic and after it for better understanding of the changes. The observations, as seen in Figure 7, show increasing in the people numbers after the lockdown due to COVID-19 pandemic where the locals started to walk and do different activities.

\subsection{Social activities}

What are the areas of social activities?

The way of activities distribution makes more questions regarding why do the large number of locals gather in the same locations and at the same time? However, the result needed a deeper understanding by analysis of the actual street elevation land use, in addition asking locals about their destination before making their activities in this street. The result has been recorded through mapping, as seen in Figure 8. As well as, making sections in different locations in the street, as seen in Figure 8, to explain the dimensions of the street.

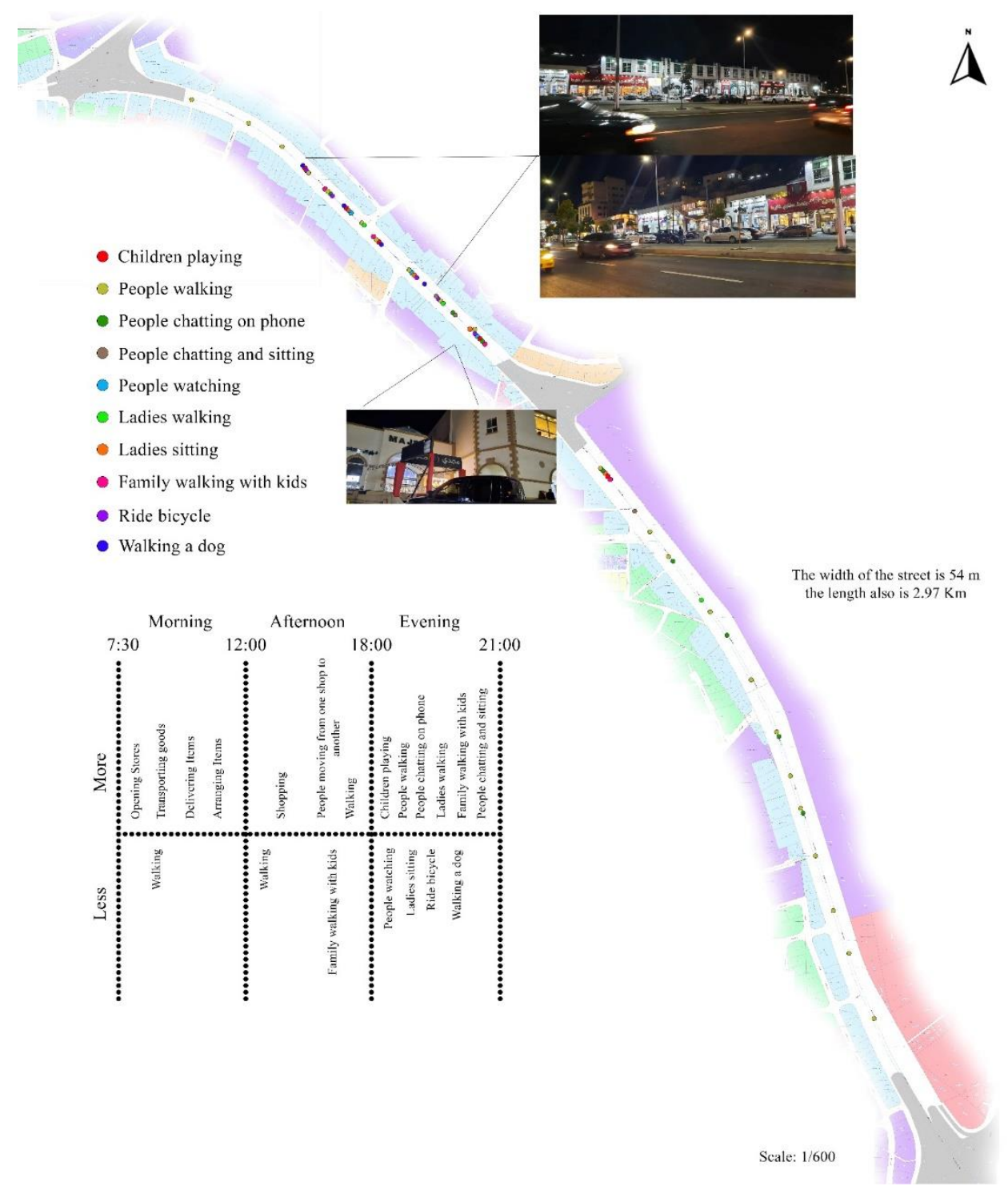

Figure 6. The activity distribution along the queen Rania street 


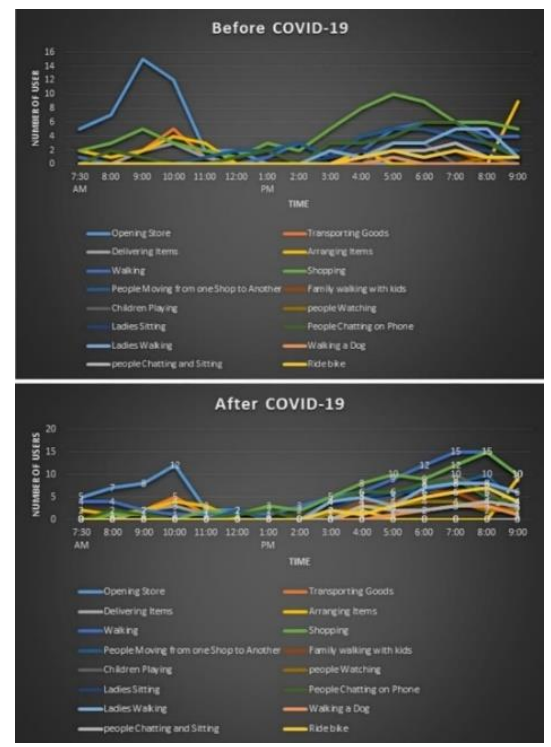

Figure 7. The type of activity throughout the day along the queen Rania street before and after the lockdown

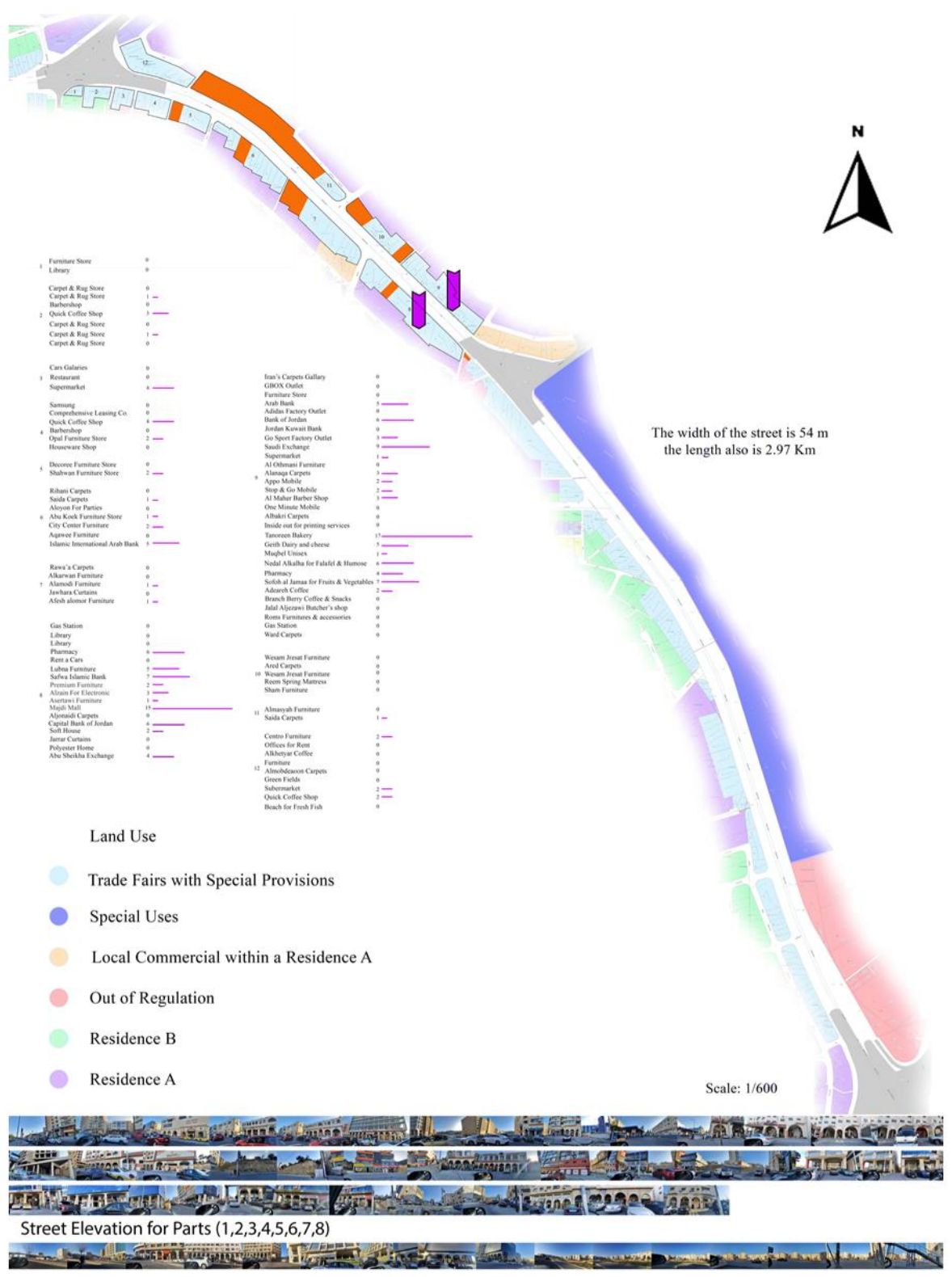

Figure 8. The type of street function and the frequency of them 


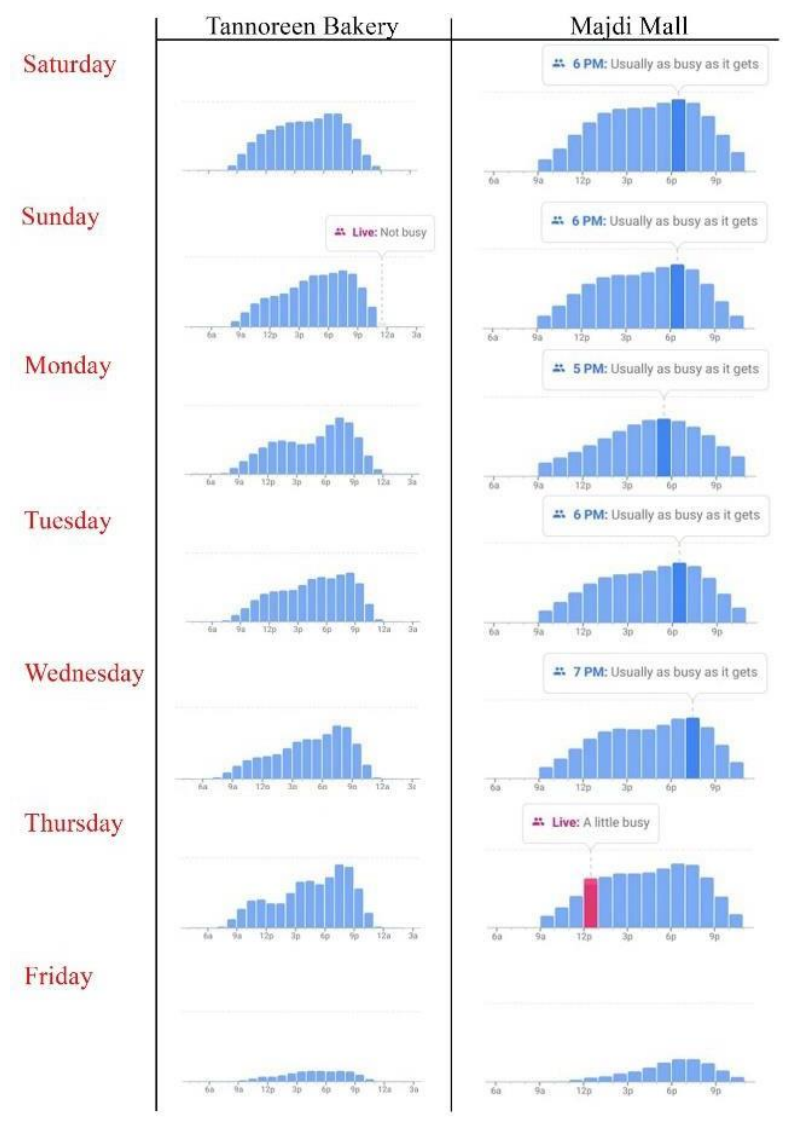

Source: (The Authors after Google Map Statistics, 2021)

Figure 9. Popular times for Majdi mall and Tannoreen bakery

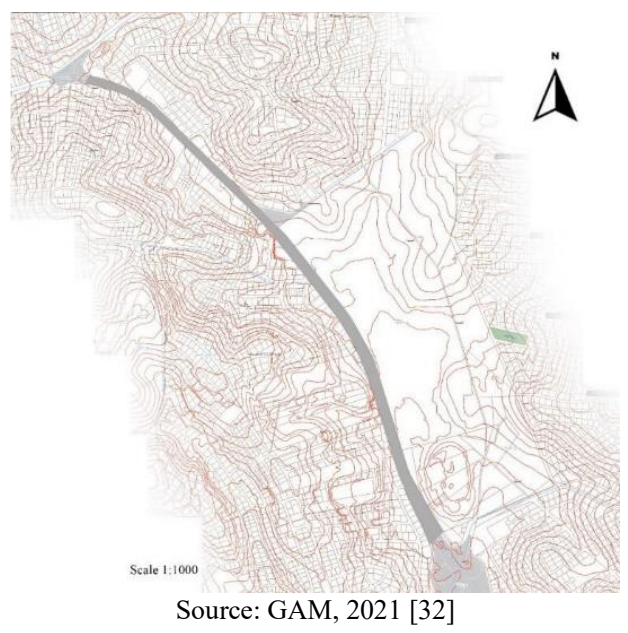

Figure 10. The topography of the queen rania street

According to the mapping analysis of actual use of the street where have reveal that most of them are furniture stores are spread along the street with low flow of customers during the day, however, the high flow of customers was remarkably at two points which are, Majdi Mall and Tannoreen Bakery, and around them there are many shops also have number of users. All that justify the results before about how locals are distributed along the street. While the second part of street was consisted of the University of Jordan on one side which was closed during the pandemic and on the second side of street was the restaurants also, they were closed at the time of this research.

By focusing on distribution of users over time for Majdi Mall and Tannoreen Bakery over the week, it appeared that the peak hours for both are relevant with what has been conducted by the observation about the walkable time in the street. In terms of Which all are concentrated at 6:00 pm to 9:00 pm, as seen in Figure 9. That shows the importance of uses of the street elevation along the street in attracting pedestrians.

However, this street is considered as the edge of two districts mainly because the steep slope whenever getting farther away from the street towered to the district. Furthermore, that can justify the continuity in the direction of locals' movement in a straight line and avoid moving in the streets perpendicular to it, as seen in Figure 10.

Questionnaires primarily conducted in June 2020 by using random selection for people who are 18 years old and above and who use selected streets. As part of the questionnaire, which is separated into four parts, the first one refers to user profile, the second one for perception of the type of usage of selected streets after and before COVID-19 lockdown and type of activities done there. The third part presents the causes behind selected or feeling belonging to these streets before the lockdown of COVID-19, and the fourth part presents after the lockdown.

This method has facilitated the way of exploring pedestrian perceptions about these streets. The questionnaire survey has given us insights about users' viewpoints concerning how these streets are significant for locals to do their activities. Furthermore, how they have found out their needs for this place as a public space after the lockdown of COVID-19. On the other hand, direct observation goes parallel to the questionnaire to present deeper examination of pedestrian behaviors and the quality of street to work as a public space.

According to conducting data, $54 \%$ of the participants in the questionnaire survey were female, which could be considered a good indicator for research, as shown in Figure 11. In 
addition, Figure 12 presents the majority of street's users are from locals who live in neighborhoods around the street.

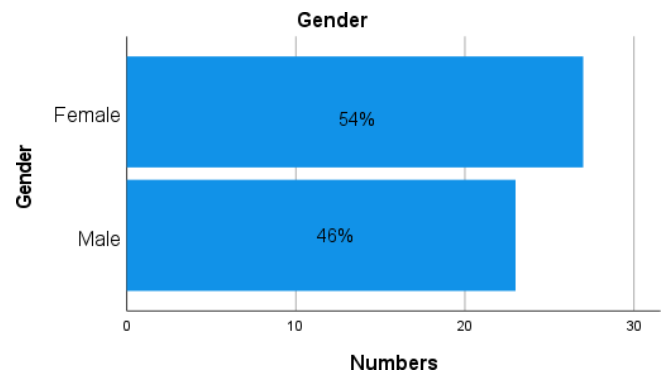

Figure 11. Types of pedestrians flow according to their gender

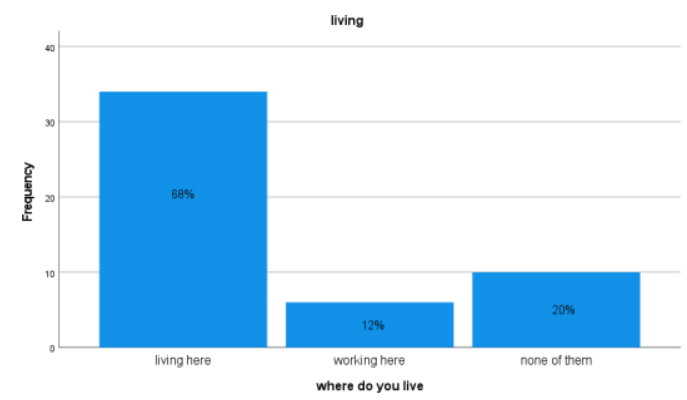

Figure 12. Types of pedestrians presence

Figure 13 represents the outcome of respondents' perception of the type of activities they had done in this street when asked to respond to the question "what kind of activities do you prefer to do in the selected street?" The response of the majority was that they are coming to the street for walk.

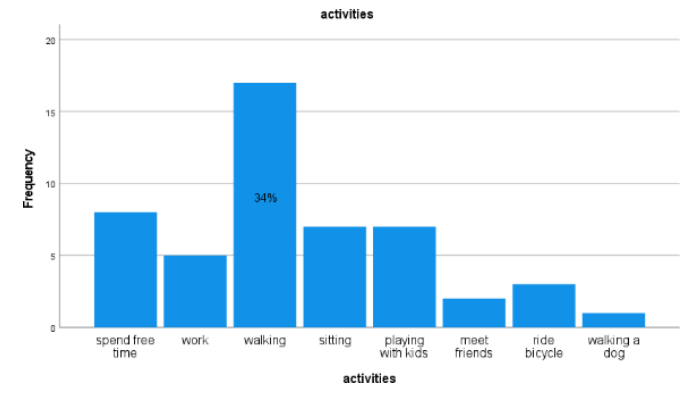

Figure 13. Types of pedestrians activities

According to Figure 14, that represents the comparison between the frequency of doing activities before and after the lockdown of COVID-19 pandemic. There is an obvious increasing in local's turnout on doing activities in this street after COVID-19 pandemic. "Several days a week" was the most frequent in people answers after the pandemic while "ones or twice a month" was the most frequent answers before the pandemic. So, there is a relationship between COVID-19 lockdown and the turnout of activities.

How do local users perceive the streets?

The locals' perceived quality of the street and usage before lockdown of COVID-19 pandemic and after, was measured using qualitative indicators that consist of sense of belonging, walkability, use of shops, safety, aesthetic, illumination, sense of interest based on questionnaire survey. The perception was measured on a Likert scale of 5 means strongly agree and 1 means strongly disagree.

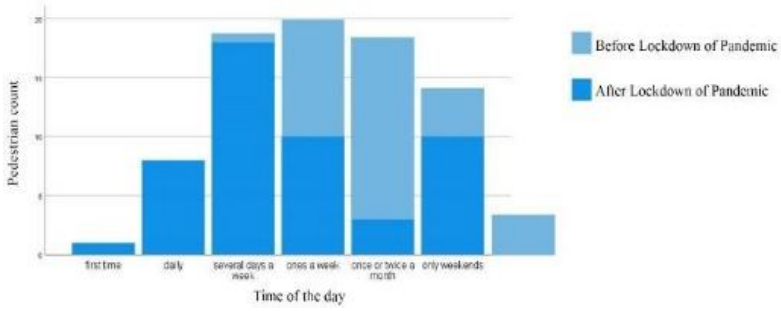

Figure 14. The perception frequency of local's activity

\subsubsection{Sense of belonging}

Figure 15 represents the outcome of respondents' perception of sense of belonging before and after lockdown of COVID-19 pandemic, obviously most of the respondents surveyed agree or strongly agree after lockdown and they feel at home and this street is like a small park for them. While the same question for before lockdown the response was mostly disagree or neutral because they basically have not gone down to the street on foot before.

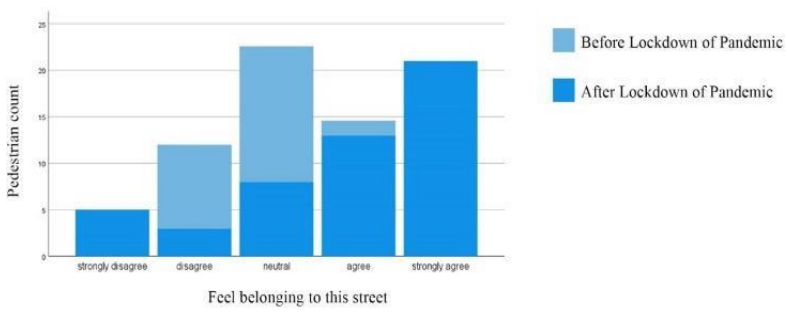

Figure 15. The perception of the sense of belonging

\subsubsection{Using shops}

The same situation when asked to respond to the statement of "you are using the shops in the street", they were the highest percentage to agree after lockdown while before lockdown they were not using largely, especially the supermarket shops, as seen in Figure 16.

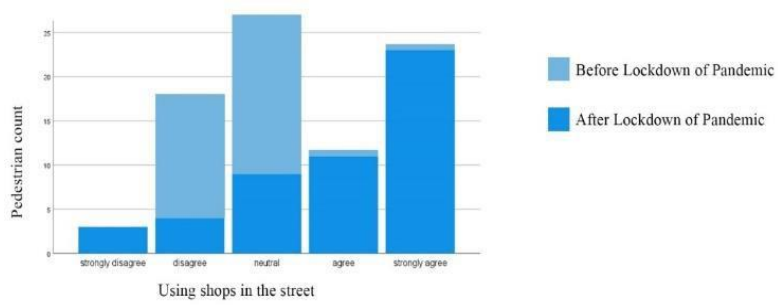

Figure 16. The perception of using shops of the street

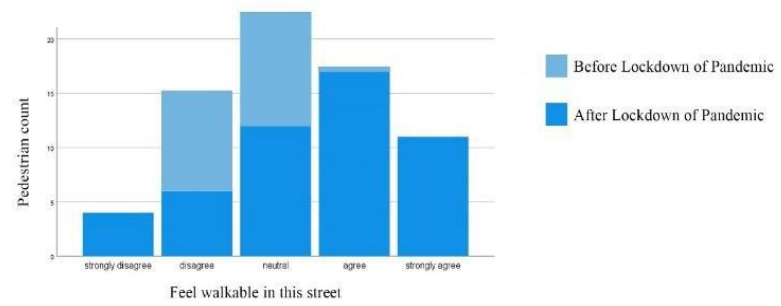

Figure 17. The perception of walkability

\subsubsection{Sense of walkable}

Figure 17 represents the respondents' perception about the statement "the functions in this street are walkable" before and after lockdown of COVID-19 pandemic, the majority perceived that after lockdown they feel the functions are more 
walkable than before. Also, the feeling of interest in walking is more obvious after lockdown when they ask in response to the statement "The street is interesting for walking" and the outcome is shown in Figure 18.

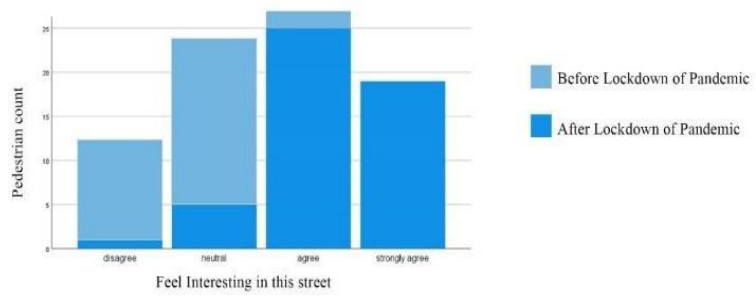

Figure 18. The perception of the sense of interesting

\subsubsection{Sense of safety}

The statements related to the sense of safety were split into three parts. The first part was related to the safety during the day after and before the lockdown and the locals' responses were little different between two situations but after lockdown, they feel more safe and secure because the number of street's users have increased. similarly, for part two that refers to the sense of safety at night and part three the sense of safety for kids in this street the answers were close with nuance in after lockdown, also still the street is not safety for kids according to the feedback of some of the locals if the fence continued along this street, we maybe feel better safety, as seen in Figure 19.

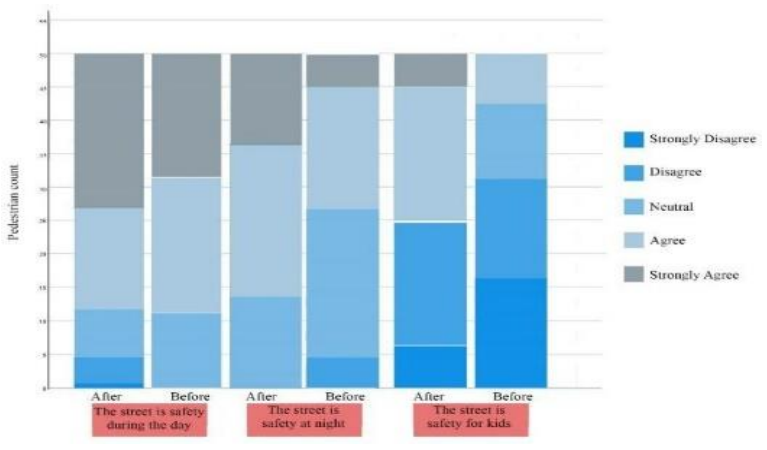

Figure 19. The perception of sense of safe during the day

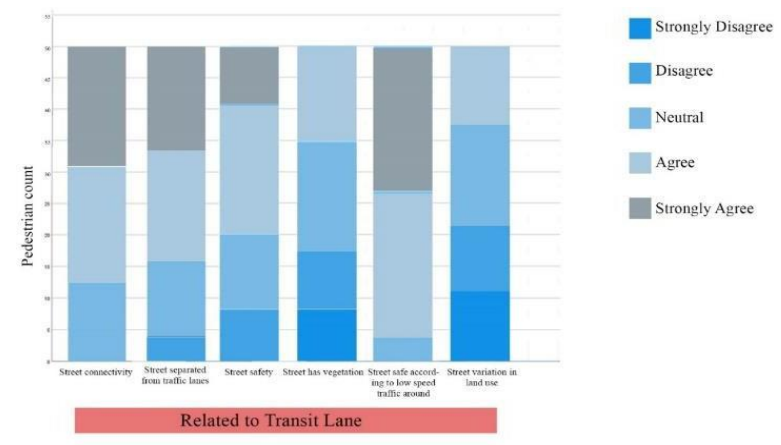

Figure 20. The perception of transit lane

The stats related to transit lane.

The questionnaire survey established part to find out why the locals prefer using transit lanes for doing their activities whether walking or sitting. It is notable that the locals prefer transit lane for many reasons for instance, the connectivity in this lane without any interruption paths to ensure the continuity in flow of people, the lane separated by middle island from vehicles lanes that give this part of street more safety and privacy, also this lane has some kind of vegetation that give enclosure to the lane and aesthetically, as seen in Figure 20).

\section{CONCLUSION AND RECOMMENDATION}

This article aimed to measure the efficiency of Queen Rania Street as a public space after the COVID-19 pandemic and explored how human behaviors changed on the street. That was through two parts the first one by making deep observations and mapped behavioral activity and the second part was by making questionnaire surveys.

The observation part focused on measuring the behavioral activity of the street in which an increasing number of users of the street was detected not just for shopping but also for doing other kinds of physical exercise such as walking, playing with kids and riding a bike. Furthermore, the mapping of the locals' activities and analyze how they work along the street and making a comparison of the locals' activities before and after the lockdown by COVID-19 pandemic all of that revealed the activities increased after lockdown and the nodes was connected with the functions on the street elevation. Locals activities are focused on the part of the street which has dynamic functions in shops. Questionnaire survey shows a better understanding of changes in locals' activities and how they feel about this street, since the sense of belonging increases when they increase use for the street and they feel like part of their neighborhood as a public space but still need some maintenance in the street quality which also evaluate the quality of the design of the street by participants' response on questionnaire.

Most streets were designed for vehicles while ignoring the pedestrian needs in pavements for a walk. However, people need sidewalks on a wider basis these days after COVID-19 than ever before in response to the current crisis to do more action to meet physical distance. whereas the streets are considered as a good opportunity for social interaction between locals such as storefront shopping, meeting with friends and for pedestrian activities. Therefore, the physical distance should be considered in designing streets.

This analysis can be further improved to get the optimization in social interaction and make this street as a public street and help the policy makers to develop designing streets to serve pedestrians more than vehicles. Also can expand this research to include Airport Street which is also faced with an increase in the number of users but not the local community; they are from other places coming by their cars to sit and do the same physical activities.

\section{REFERENCES}

[1] Alter, L. (2020) Urban Design after the Coronavirus. https://www.treehugger.com/urban-design.

[2] Florida, R. (2020). We'll need to reopen our cities. But not without making changes first. CityLab. https://www.citylab.com/equity/2020/03/coronavirus.

[3] Lipovsky, C. (2021) Social distancing in the time of COVID-19: A case study from Australia, Academia Letters.

[4] Carmona, M., Tiesdell, S., Heath, T., Oc, T. (2010) Public Places Urban Spaces: The Dimensions of Urban Design (2nd ed.). London: Routledge Taylor \&Francis 
Group.

[5] Babatunde, O. (2015). Importance of effective communication in public organisations. Issues in Social Science, $3(2)$ : 78-89. https://doi.org/10.5296/iss.v3i2.8596

[6] Department of Statistics (DOS). (2020). Amman, Jordan.

[7] Ministry of Health (MOH). (2020). Amman, Jordan.

[8] Alqutob, R., Al Nsour, M., Tarawneh, M., Ajlouni, M., Khader, Y., Aqel, I., Kharabsheh, S., Obeidat, N. (2020) COVID-19 crisis in Jordan: Response, scenarios, strategies, and recommendations. JMIR Public Health and $\quad$ Surveillance, $6(3)$ e 19332. https://doi.org/10.2196/19332

[9] Anderson, R., Chin, S., Dara, N., Harlos, D., Johnson, E., Jordan Times. (2020). Jordan Strategy Forum paper strategises over coronavirus policy http://www.jordantimes.com/news/local/jordanstrategy-forum-paper-strategises-over-coronaviruspolicy.

[10] Labahn, S., LaRocque, E., Lloyd, G., Lone, S., McBurnie, M., Nakao, T., Nesbitt, C., Oswald, T., Raphael, L., Shen, H., van der Veen, A., Zhou, S., Villagomez, E., HoneyRosés, J. (2018). Life in Poblenou: Observation and Exploration. School of Community and Regional Planning. University of British Columbia. https://dx.doi.org/10.14288/1.0372821

[11] Walmsley, D.J. (1988). Urban living: The individual in the city. Pearson/Education. https://doi.org/10.1016/S0272-4944(89)80008-8

[12] Gehl, J., Svarre, B. (2013). How to Study Public Life. Washington, DC: Island Press http://dx.doi.org/10.5822/978-1-61091-525-0

[13] Ciocoletto, A. (2014). Espacios para la Vida Cotidiana: Auditoria de Calidad Urbana con Perspectiva de Genero. " PATRIMONIO": Economía Cultural y Educación para la Paz (MEC-EDUPAZ), 2(18): 1-73.

[14] Cheshmehzangi, A., Heat, T. (2012). Urban identities: Influences on socio-environmental values and spatial inter-relations. Procedia-Social and Behavioral Sciences, 36:

253-264 https://doi.org/10.1016/j.sbspro.2012.03.028

[15] Darmayanti, T., Bahauddin, A. (2020). Understanding vernacularity through spatial experience in the peranakan House Kidang Mas, Chinatown, Lasem, Indonesia. Journal of the International Society for the Study of Vernacular Settlements, 7(3): 1-13.

[16] Nowak, S., Wierzbicki, R. (2016). Diagnoza społeczna zapotrzebowania na infrastrukturę sportowo-rekreacyjną. Raport $\mathrm{z}$ badania jakościowego i omnibusowego, MSiT, GFK.

[17] Kostrzewska, M. (2017) Activating pu environment, Gdansk university of technology, Faculty of Architecture, ul. Narutowicza, Materials Science and Engineering 11(12): $\quad 80-233 . \quad$ https://doi.org/10.1088/1757$899 X / 245 / 5 / 052074$

[18] Khawaja, H. (2015). Public Spaces under Threat: Scenes from Amman. Research Master Planning and Sustainability: Urban and Regional Planning. Polytech university tour. France.

[19] Hermann, R. Keuss, R. (2021). URBANET, News and Debates on Municipal and Local Governance. Sustainable Urban Development and Decentralisation.
[20] Abu-Ghazzeh, T.M. (1996). Reclaiming public space: The ecology of neighborhood open spaces in the town of Abu-Nuseir, Jordan. Landscape and Urban Planning, 36(3): $\quad 197-216$. https://doi.org/10.1016/S01692046(96)00343-X

[21] Höök, M., Jonsson, P., Skottke, E., Thelandersson, M. (2012). Korogocho streetscapes: Documenting the role and potentials of streets in citywide slum upgrading. UN Habitat.

[22] Wijesundara, J. Weerasinghe, U. Perer, L. (2021). Inhabitants' Satisfaction in Neighbourhood Sustainability: Insights from Colombo. ISVS e-journal, 8(1): 64-76.

[23] Frank, L., Sallis, J., Saelens, B., Leary, L., Cain, K., Conway, T., Hess, P.M. (2010). The Development of a Walkability Index: Application to the Neighborhood Quality of Life Study. British Journal of Sports, 44(13): 924-933. https://doi.org/10.1136/bjsm.2009.058701

[24] Shumi, S. (2013). Understanding the relationship between walkability and quality of life of women garments workers in Dhaka, Bangladesh. University of Twente Faculty of Geo-Information and Earth Observation(ITC).

http://www.itc.nl/library/papers 2013/msc/upm/shumi.p df.

[25] Sadik-Khan, J., Solomonow, S. (2017). Streetfight: Handbook for an urban revolution. Penguin.

[26] Nieuwenhuijsen, M. (2020). Urban and transport planning pathways to carbon neutral, liveable and healthy cities; a review of the current evidence. Environment International, 140: 105661. https://doi.org/10.1016/j.envint.2020.105661

[27] Roberts, D. (2020). How to make a city livable during lockdown. Vox. https:/www.vox.com/cities.

[28] EFE, 2020 Milan le quitara al coche $35 \mathrm{~km}$ de carriles para darselos a la bici y el peaton. El Periódico, Available at:

https://www.elperiodico.com/es/internacional/20200421 /milan-le-quitara-al-coche-35-km-de-carriles-paradarselos-a-la-bici-y-el-peaton-7935410.

[29] Hawkins, A. (2020). There's no better time for cities to take space away from cars. Verge. Available at: https://www.theverge.com/2020/3/23/21191325/citiescar-free-coronavirus-protected-bike-lanes-air-qualitysocialdistancing.

[30] Mehmet, S. (2020). TfL and Mayor unveil postlockdown London infrastructure programme. Intelligent Transport.

https://www.intelligenttransport.com/transportnews/98627/tfl-and-mayor-unveil-post-lockdownlondon-infrastructure-programme.

[31] Topham, G. (2020). London pedestrians and cyclists may get more space on roads, https:/www.theguardian.com/uknews/2020/apr/14/london-pedestrians-and-cyclist-mayget-more-space-on-roads-during-coronavirus-lockdown.

[32] Jacobs, A. (1985). Looking at Cities. Cambridge: Harvard University Press.

[33] Appleyard, D., Lintell, M. (1972). The environmental quality of city streets: The residents' viewpoint. Journal of the Merican Institute of Planners, 38(2): 84-101. https://doi.org/10.1080/01944367208977410 